\title{
Shallow core drilling of the Upper Cretaceous Chalk at Stevns Klint, Denmark
}

\author{
Lars Stemmerik, Finn Surlyk, Kurt Klitten, Susanne L. Rasmussen \& Niels Schovsbo
}

The Upper Cretaceous - Danian succession in Denmark and most of NW Europe is composed mainly of chalk and associated shallower water carbonates deposited in a wide epeiric sea during an overall global sea-level highstand (e.g. Surlyk 1997). The Maastrichtian-Danian chalk has been intensely studied over the last 20 years, since it forms the most important reservoir rock for hydrocarbons in the North Sea Central Graben (e.g. Surlyk et al. 2003; Klinkby et al. 2005). In Denmark, thousands of water wells have been drilled through the succession as about $35 \%$ of the water consumption is from Maastrichtian chalk and Danian bryozoan limestone.

During 2005 the new Cretaceous Research Centre (CRC) was established jointly at Geocenter Copenhagen by the Geological Institute, University of Copenhagen and the Geo- logical Survey of Denmark and Greenland (GEUS) with financial support from the Danish Natural Science Research Council (FNU). CRC aims at studying the Earth System in a Greenhouse World, with special emphasis on the Upper Cretaceous - Danian chalk of NW Europe. The stable, longlasting marine macro-environment represented by the chalk sea provides a unique opportunity to analyse and link the depositional, geochemical and biological responses to external forcing at time scales ranging from the sub-Milankovitch to the million year range. The studies will be based on a wide range of methods, including seismic stratigraphy, palaeoecology, sequence-, cyclo- and biostratigraphy, isotope geochemistry, sedimentology and time series analysis. This paper presents the first preliminary results of a CRC drilling cam-
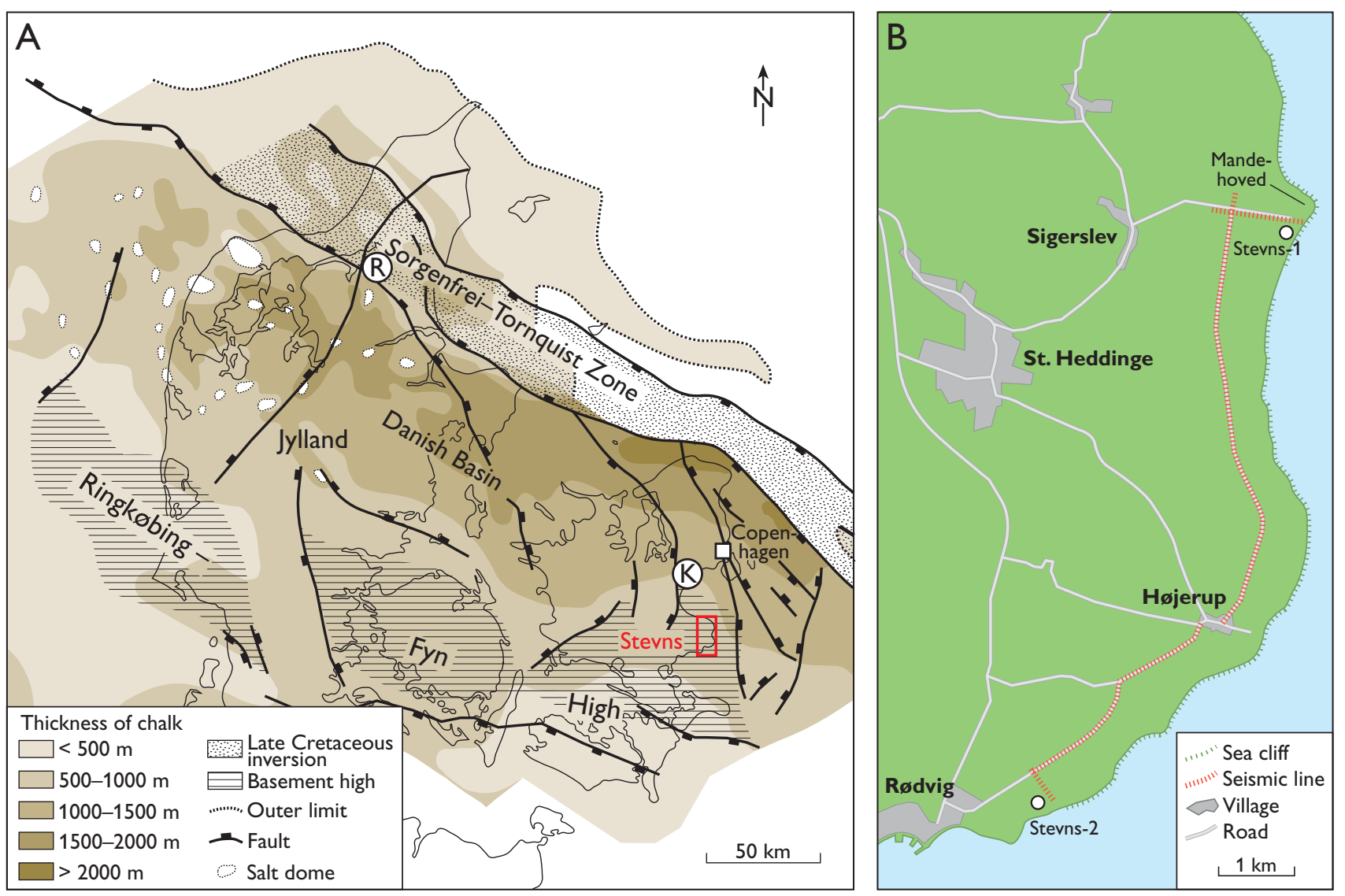

Fig. 1. A. Thickness of the Upper Cretaceous - Danian chalk in the Danish area. R: Rørdal quarry; K: Karlslunde-1 and Tune-1 boreholes. B. Map of the study area at Stevns showing the location of the Stevns-1 and Stevns-2 boreholes. 


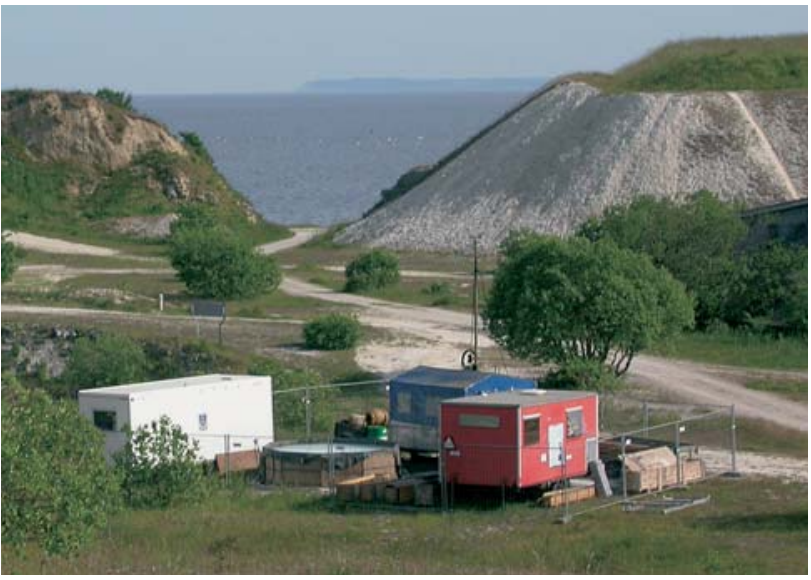

Fig. 2. The Fakse Kalk A/S Diamant Board 747 wireline rig at the site of Stevns- 2 in the abandoned Boesdal quarry north-east of Rødvig.

paign at Stevns Klint, eastern Denmark (Fig. 1), where two shallow boreholes were drilled and logged from near the base of the Danian bryozoan limestone and down through the upper 350-450 m of the very thick Upper Cretaceous chalk section (Vejbæk et al. 2003). The cores represent the first complete sections through the Maastrichtian chalk of eastern Denmark.

\section{Shallow core drilling}

Seismic data from the offshore area immediately to the east of Stevns Klint indicate that chalk deposits in this area were modified by powerful, long-lasting bottom currents, and that the Late Cretaceous sea floor was continuously sculpted by contour-parallel bottom currents into systems of ridges and drifts, moats and valleys with amplitudes up to $150 \mathrm{~m}$ and widths of several kilometres (Lykke-Andersen \& Surlyk 2004; Esmerode et al. in press). In order to investigate the lithological composition of this dynamic chalk system and to provide material for time series analysis, two shallow boreholes were drilled and cored along Stevns Klint from near the base of the Danian bryozoan limestone and 350-450 m down into the Upper Cretaceous chalk (Fig. 1). The northern borehole, Stevns-1 (DGU 218.1938) approximately $2 \mathrm{~km}$ east of Sigerslev was drilled near the culmination of the undulating K-T boundary surface, and is believed to penetrate a ridge succession (Fig. 1). The southern borehole, Stevns-2 (DGU 218.1945) north-east of Rødvig was drilled on a depression in the undulating $\mathrm{K}-\mathrm{T}$ boundary surface, and was drilled to penetrate a valley-fill succession (Figs 1,2).

A comprehensive logging program was subsequently carried out in the two boreholes including spectral gamma, density, sonic, induction, temperature, conductivity, porosity, magnetic

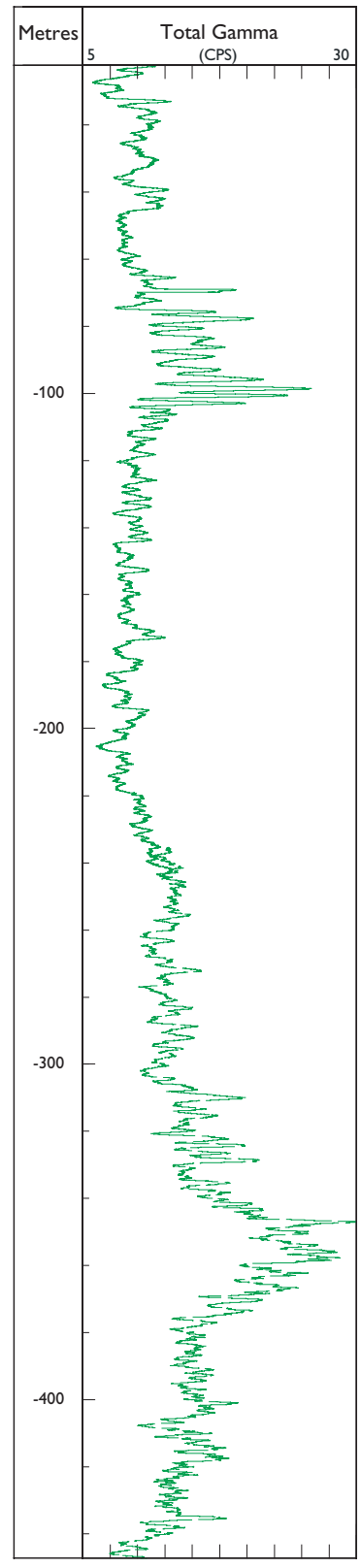

Fig. 3. Gamma-ray log of Stevns-1 showing the presence of two marl-rich intervals from c. 65-100 $\mathrm{m}$ and $345-370 \mathrm{~m}$. susceptibility, resistivity and optic televiewer logs. Logging was carried out in open hole using standard methods.

Stevns-1 was drilled to a depth of $456.1 \mathrm{~m}$ with $100 \%$ core recovery. It penetrated approximately $12 \mathrm{~m}$ of Danian bryozoan limestone before entering the Maastrichtian chalk succession. Preliminary nannofossil data (E. Sheldon, personal communication 2005) indicate that the Maastrichtian chalk is approximately $400 \mathrm{~m}$ thick and that the basal part of the drilled succession is of Late Campanian age. The drilled succession is roughly divided into an upper Campanian - lowermost Maastrichtian interval of bioturbated chalk with rare thin clay beds that gradually passes up into a $50 \mathrm{~m}$ thick succession of interbedded lower Maastrichtian chalk and marl. The gamma ray log indicates that marl layers become gradu- 
ally less abundant upwards, and the interval from 300-100 m is composed of almost pure chalk (Fig. 3). The first flint nodules and layers appear at $135 \mathrm{~m}$ and flint is common in the upper part of the succession. The 100-70 m interval consists of flint-rich chalk with distinctive marly horizons while the uppermost part of the Maastrichtian succession shows an increasing content of bryozoans and other macrofossils.

Stevns- 2 was drilled to a depth of $350 \mathrm{~m}$ with $100 \%$ core recovery. It penetrated $4 \mathrm{~m}$ of Danian limestone and approximately $300 \mathrm{~m}$ of Maastrichtian chalk before it terminated in upper Campanian chalk. The drilled succession shows the same overall changes in lithology as Stevns-1 but the thickness of the individual units seem to vary considerably. This is particularly true for the chalk-dominated succession between the two marly intervals which thins from approximately 200 $\mathrm{m}$ in Stevns-1 to $120-130 \mathrm{~m}$ in Stevns-2.

\section{Core scanning}

The $456.1 \mathrm{~m}$ long Stevns-1 core has been scanned at the GEUS core laboratory using a set-up which allows simultaneous spectral gamma-ray and density measurements (Fig. 4). The spectral gamma-ray analysis is carried out using two 15 $\mathrm{cm} \mathrm{NaI}(\mathrm{Tl})$ crystals and the bulk density is determined using a caesium source. The scanning was performed using a speed of $1 \mathrm{~cm} / \mathrm{min}$., corresponding to a vertical resolution of approximately $2 \mathrm{~cm}$ for the density log. The scanning data thus supply high resolution data to support sedimentary and geochemical data from the core, as exemplified in Fig. 4 illustrating the cyclic nature of the succession. In this interval Uranium only shows minor variations and the high total gamma readings correspond to $\mathrm{K}$ - and Th-peaks. It is thus evident that these peaks correspond to marly beds with high levels of clay-bound $\mathrm{K}$ and $\mathrm{Th}$ whereas intervals with low total gamma readings correspond to purer chalk.

\section{Comparison with other Danish chalk sections}

The Stevns-1 and Stevns-2 cores represent the first complete sections through the Maastrichtian chalk of eastern Denmark. The uppermost up to $35 \mathrm{~m}$ of the Maastrichtian are exposed along Stevns Klint and in quarries along the cliff. Further south, on the island of Møn, approximately $70 \mathrm{~m}$ of lower Maastrichtian chalk occur as glacially disturbed thrust sheets in excellent cliff exposures dominated by flint-rich bioturbated chalk with rare incipient hardgrounds; at Stevns Klint the youngest Maastrichtian deposits become gradually richer in bryozoans. The main difference between the cored section and the adjacent outcrops is the lack of flint in the deeper part of the core.

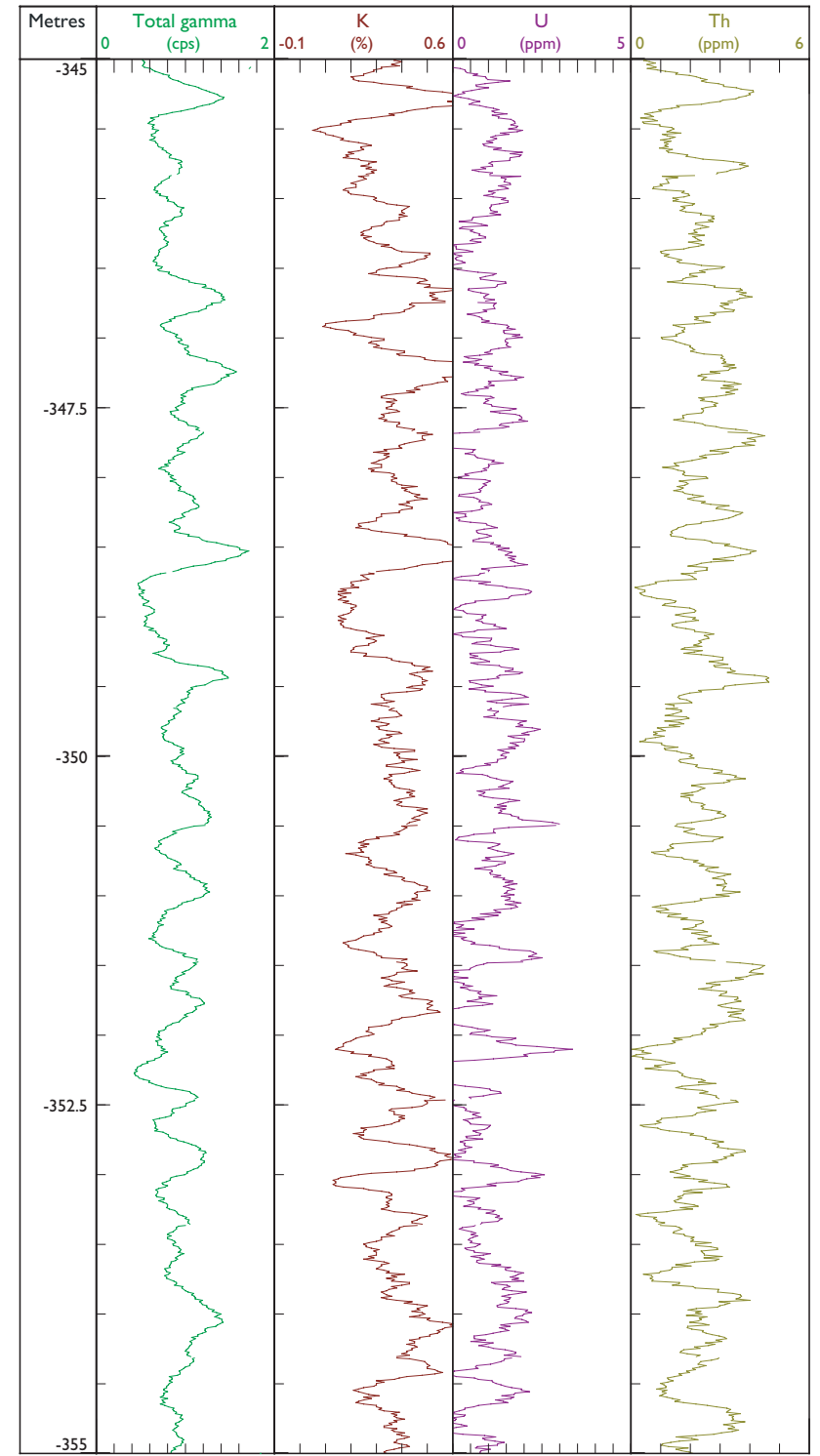

Fig. 4. Core scan log of the 345-355 m interval in Stevns-1 showing total gamma response and $\mathrm{K}, \mathrm{U}$ and Th concentrations. Note that intervals with high total gamma correlate with high concentrations of $\mathrm{K}$ and $\mathrm{Th}$, and correspond to marly beds.

The Danian - uppermost Maastrichtian succession has been drilled by numerous water wells in the greater Copenhagen area to the north and north-west of Stevns Klint, and more recently the upper $250 \mathrm{~m}$ of the Maastrichtian chalk were cored in Tune-1 (DGU 207.3841) and Karlslunde-1 (DGU 207.3850; Fig. 1; Larsen et al. 2006). These two cores show a facies development similar to that seen in the upper part of the Stevns cores with a downward change from bryozoan-rich chalk to bioturbated chert-rich chalk interrupted in the mid-Maastrichtian by a succession of interbedded marl 
and chalk layers before the core bottoms in midMaastrichtian chalk (Larsen et al. 2006). The most important difference is the presence of a distinctive $20 \mathrm{~cm}$ thick marl, interpreted as representing the Kjølby Gaard Marl of Troelsen (1937, 1955), 9-10 m below the K-T boundary in Tune-1. This marl has also been reported from adjacent water wells (Larsen 1997) and in quarries in northern Jylland (Troelsen 1955), and seems to be a distinctive stratigraphic marker bed in northern Denmark. The mid-Maastrichtian interval of interbedded chalk and marl drilled in Stevns-1, Stevns-2 and Karlstrup-1 also seems to represent a distinctive regional event as a similar cyclic chalk-marl succession is known from the Rørdal quarry in northern Jylland.

\section{Future work}

The Stevns cores represent the first continuous sections of the Maastrichtian chalk in NW Europe and provide a unique possibility for sedimentological, geochemical and isotope geochemical investigations as well as time series analysis and studies of reservoir properties. The Stevns area has been buried to less than 600-700 m during post-Danian time and the lack of burial diagenetic overprinting makes the carbonates ideal for isotope geochemical analyses to monitor both the global carbon cycle and to provide information on the temperature and salinity of the Late Cretaceous Boreal Ocean.

Core data will be integrated with log data to better understand the lithological significance of the log responses, and $2 \mathrm{D}$ depositional models of the chalk will be based on integration of core and log data with reflection seismic data along a line connecting the two boreholes. Reflection seismic data have been collected between the two boreholes in cooperation with Holger Lykke-Andersen, University of Aarhus, and refraction seismic data have been collected by Lars Nielsen, University of Copenhagen. The two data sets are still in the stage of processing but will provide important $2 \mathrm{D}$ data to support the information from the cores.

\section{Acknowledgements}

The Danish Natural Science Research Council is thanked for financial support. Additional funding for logging has been obtained from Geocenter Copenhagen. Fakse Kalk A/S and Rambøll A/S provided technical assistance. Stevns Kommune and Stevns Natur Center kindly allowed us to drill at their property.

\section{References}

Esmerode, E.V., Lykke-Andersen, H. \& Surlyk, F. in press: Ridge and valley systems in the Upper Cretaceous chalk of the Danish Basin: contourites in an epeiric sea. Geological Society of London, Special Issue.

Klinkby, L., Kristensen, L., Nielsen, E.B., Zinck-Jørgensen, K. \& Stemmerik, L. 2005: Geological characterisation of the Kraka Field chalk reservoir, Danish North Sea - integration of seismic and log data. Petroleum Geoscience 11, 113-124.

Larsen, F., Sonnenborg, T.O., Madsen, P., Ulbak, K.A. \& Klitten, K. 2006: Saltvandsgræensen i kalkmagasinerne i Nordøstsjælland; Delrapport 6: Saltvandsudvaskning i Danienkalk og Skrivekridt - Detailundersøgelser i Karlslunde værkstedsområde. Danmarks og Grønlands Geologiske Undersøgelse Rapport 2006/21, 103 pp.

Larsen, O. 1997: Mapping of the Maastrichtian-Danian boundary in the coastal area of Køge Bugt by gamma and resistivity logging. Bulletin of the Geological Society of Denmark 44, 101-113.

Lykke-Andersen, H. \& Surlyk, F. 2004: Topography of the CretaceousPalaeogene boundary at Stevns Klint, Denmark: Inversion tectonics or primary relief of the chalk sea-floor? Journal of the Geological Society (London) 161, 343-352.

Surlyk, F. 1997: A cool-water carbonate ramp with bryozoan mounds: Late Cretaceous - Danian of the Danish Basin. In: James, N.P. \& Clarke, J.A.D. (eds): Cool-water carbonates. SEPM (Society for Sedimentary Geology) Special Publication 56, 293-307.

Surlyk, F., Dons, T., Clausen, C.K. \& Higham, J. 2003: Upper Cretaceous. In: Evans, D., Graham, C., Armour, A. \& Bathurst, P. (eds/coordinators): The Millennium Atlas: petroleum geology of the central and northern North Sea, 213-233. London: Geological Society.

Troelsen, J.C. 1937: Om den stratigrafiske inddeling af Skrivekridtet i Danmark. Meddelelser fra Dansk Geologisk Forening. Bulletin of the Geological Society of Denmark 9, 260-263.

Troelsen, J.C. 1955: Globotruncana in the White Chalk of Denmark. Micropaleontology 1, 76-82.

Vejbæk, O.V., Bidstrup, T., Britze, P., Erlstrøm, E., Rasmussen, E.S. \& Sivhed, U. 2003: Chalk structure map of the central and eastern North Sea. Danmarks og Grønlands Geologiske Undersøgelse Rapport 2003/106, 55 pp.

\footnotetext{
Authors' addresses

L.S., S.L.R., K.K. \& N.S., Geological Survey of Denmark and Greenland, Geocenter Copenhagen, Øster Voldgade 10, DK-1350 Copenhagen K, Denmark. E-mail: ls@geus.dk

F.S., Geological Institute, University of Copenhagen, Geocenter Copenhagen, Øster Voldgade 10, DK-1350 Copenhagen K, Denmark.
} 